\title{
A Newly Identified Younger Dryas Component in Eagle Cave, Texas
}

\author{
Charles W. Koenig (D), J. David Kilby (D), Christopher J. Jurgens (D, Lorena Becerra-Valdivia (D), \\ Christopher W. Ringstaff (D), J. Kevin Hanselka (D), Leslie L. Bush (D), Charles D. Frederick (D), \\ Stephen L. Black (D), Amanda M. Castañeda (1), Ken L. Lawrence (D), Madeline E. Mackie (i), \\ and Jim I. Mead
}

\begin{abstract}
Recent excavations by the Ancient Southwest Texas Project of Texas State University sampled a previously undocumented Younger Dryas component from Eagle Cave in the Lower Pecos Canyonlands of Texas. This stratified assemblage consists of bison (Bison antiquus) bones in association with lithic artifacts and a hearth. Bayesian modeling yields an age of 12,660-12,480 cal BP, and analyses indicate behaviors associated with the processing of a juvenile bison and the manufacture and maintenance of lithic tools. This article presents spatial, faunal, macrobotanical, chronometric, geoarchaeological, and lithic analyses relating to the Younger Dryas component within Eagle Cave. The identification of the Younger Dryas occupation in Eagle Cave should encourage archaeologists to revisit previously excavated rockshelter sites in the Lower Pecos and beyond to evaluate deposits for unrecognized, older occupations.
\end{abstract}

Keywords: Younger Dryas, Paleoindian, rockshelter, Texas, Lower Pecos Canyonlands, zooarchaeology, Bayesian modeling, macrobotanical analysis

Excavaciones recientes realizadas por el Proyecto Ancient Southwest Texas of Texas State University, muestrearon un componente Dryas Reciente no documentado previamente para el sitio Eagle Cave en la región de cañones del Bajo Pecos en Texas. Este conjunto estratificado consiste en huesos de bisonte (Bison antiquus) en asociación con artefactos líticos y una vivienda. Modelos Bayesianos producen una fecha de 12.660-12.480 cal aP, y los análisis indican procedimientos asociados con el procesamiento de bisonte joven y la fabricación y mantenimiento de herramientas líticas. Este articulo presenta análisis espaciales, faunísticos, macrobotanicos, cronométricos, geoarqueológicos y líticos relacionados con el componente Dryas Reciente dentro de Eagle Cave. La identificación de la ocupación Dryas Reciente en Eagle Cave debería animar a los arqueólogos a revisitar los sitios en los abrigos rocosos previamente excavados en el Bajo Pecos para después evaluar los depósitos de ocupaciones antiguas no reconocidas.

Palabres claves: Dryas Reciente, Paleoamericano, abrigos rocosos, Texas, región de cañones del Bajo Pecos, zooarqueología, modelos Bayesianos, análisis macrobotanico

\footnotetext{
Charles W. Koenig (corresponding author, ckoenig@ uwyo.edu) — Anthropology Department, University of Wyoming, Laramie, WY, USA
}

J. David Kilby, Christopher J. Jurgens, and Stephen L. Black — Department of Anthropology, Texas State University, San Marcos, TX, USA

Lorena Becerra-Valdivia — Oxford Radiocarbon Accelerator Unit, Research Laboratory for Archaeology and the History of Art, School of Archaeology, Oxford, UK

Christopher W. Ringstaff and J. Kevin Hanselka $\square$ Texas Department of Transportation, Austin, TX, USA

Leslie L. Bush $\square$ Macrobotanical Analysis, Manchaca, TX, USA

Charles D. Frederick $\square$ Department of Geography and the Environment, University of Texas at Austin, and Consulting Geoarchaeologist, Dublin, TX, USA

Amanda M. Castañeda $\square$ Wyoming State Historic Preservation Office Cultural Records Office, Laramie, WY, USA

Ken L. Lawrence - SWCA Environmental Consultants, Austin, TX, USA

Madeline E. Mackie $\square$ Department of Sociology and Anthropology, Weber State University, Ogden, UT, USA

Jim I. Mead $\square$ Mammoth Site, Hot Springs, SD, USA

\section{American Antiquity 87(2), 2022, pp. 377-388}

Copyright (C) The Author(s), 2021. Published by Cambridge University Press on behalf of the Society for American Archaeology. This is an Open Access article, distributed under the terms of the Creative Commons Attribution licence (https://creativecommons.org/licenses/by/4.0/), which permits unrestricted re-use, distribution, and reproduction in any medium, provided the original work is properly cited.

doi:10.1017/aaq.2021.126 
$\mathrm{T}$ The archaeological record of the Lower Pecos Canyonlands (LPC) of Southwest Texas and northeast Mexico is best known for the Holocene hunter-gatherer record preserved within rockshelters and caves. The region also contains a record of late Pleistocene archaeology, although it is poorly documented and apparently rarer than on the adjacent Edwards Plateau and Southern High Plains (e.g., Bousman et al. 2004; Holliday 1997). Of the dozens of excavated LPC sites, only six report late Pleistocene radiocarbon dates (Turpin and Eling 2017:Table 2; Supplemental Text 1), and only Bone Bed 2 at Bonfire Shelter demonstrates unequivocal Early Paleoindian (fluted point) use of the LPC (Bousman et al. 2004).

Located in the same canyon as Bonfire Shelter, Eagle Cave (EC) is one of the largest occupied rockshelters in the LPC. Although previous excavations at EC were extensive (Davenport 1938; Ross 1965), recent work by the Ancient Southwest Texas (ASWT) Project at Texas State University identified an Early Paleoindian occupation. Here we describe results of spatial, faunal, macrobotanical, chronometric, geoarchaeological, and lithic analyses on a discrete Younger Dryas occupation at EC. This component consists of Bison antiquus bones in direct association with chipped stone artifacts and a hearth. Radiocarbon dating and Bayesian age modeling place the age of the assemblage between 12,660 and 12,480 cal BP. The age of the occupation overlaps with the Folsom period, but no Folsom diagnostics were recovered. Faunal and lithic analysis indicates secondary or tertiary processing of at least one juvenile Bison antiquus, whereas macrobotanical analysis of the hearth identified potentially economic plant remains including mesquite (Prosopis sp.), indicating a summer occupation. Based on contrasting artifact assemblages between Eagle Cave and Bone Bed 2 at Bonfire, we consider the possibility that EC represents a camp associated with bison kills at Bonfire.

\section{The Lower Pecos Canyonlands and Paleoindian Archaeology}

The LPC archaeological region is centered on the confluence of the Rio Grande and Pecos Rivers in southwest Texas and Coahuila, Mexico (Figure 1). Archaeological work has focused primarily on rockshelters due to their excellent preservation and elaborate Pecos River-style pictographs (e.g., Boyd 2016; Shafer 2013). The Pleistocene megafauna from Cueva Quebrada (Lundelius 1984) and Bone Bed 1 at Bonfire Shelter (Bement 1986) may represent pre-Clovis occupations, but these components lack stone tools, and whether the broken bones at the sites are archaeological in nature remains contentious (Kilby et al. 2021). The remains of a butchered Bison antiquus were recovered from deposits more than 9550 radiocarbon years BP within Arenosa Shelter, but these remains are undated (Jurgens 2005). Clovis points are present in the region (e.g., Norris et al. 2019), but no Clovis-age components are known.

The only unequivocal LPC fluted-point component is Bone Bed 2 (BB2) at Bonfire Shelter. This rockshelter contains the remains of Bison antiquus associated with Folsom and Plainview projectile points; it may be the oldest and southernmost bison jump in North America (Bement 2007; Dibble and Lorrain 1968). Although some question interpretations of BB2 as a jump (Byerly et al. 2005), there is consensus that it reflects bison hunting by late Pleistocene foragers. The discovery of a second Younger Dryas component in the LPC significantly increases knowledge of Paleoindian occupations in both the LPC and Texas, particularly given the rarity of Early Paleoindian rockshelter occupations continentally.

\section{Eagle Cave}

Eagle Cave (41VV167) is located in Val Verde County, Texas, approximately $400 \mathrm{~m}$ downstream from Bonfire Shelter within Eagle Nest Canyon, a short tributary of the Rio Grande (Koenig et al. 2017:Figure 1). It was first excavated in the 1930s by Gila Pueblo (Sayles 1935) and the Witte Museum (Davenport 1938), followed by extensive excavations by the University of Texas in the 1960s (Ross 1965). These efforts focused on the site's center (Figure 1) and ceased at a stratigraphic zone consisting entirely of rockshelter-derived sediments (Davenport 1938:5; Ross 1965:23, 

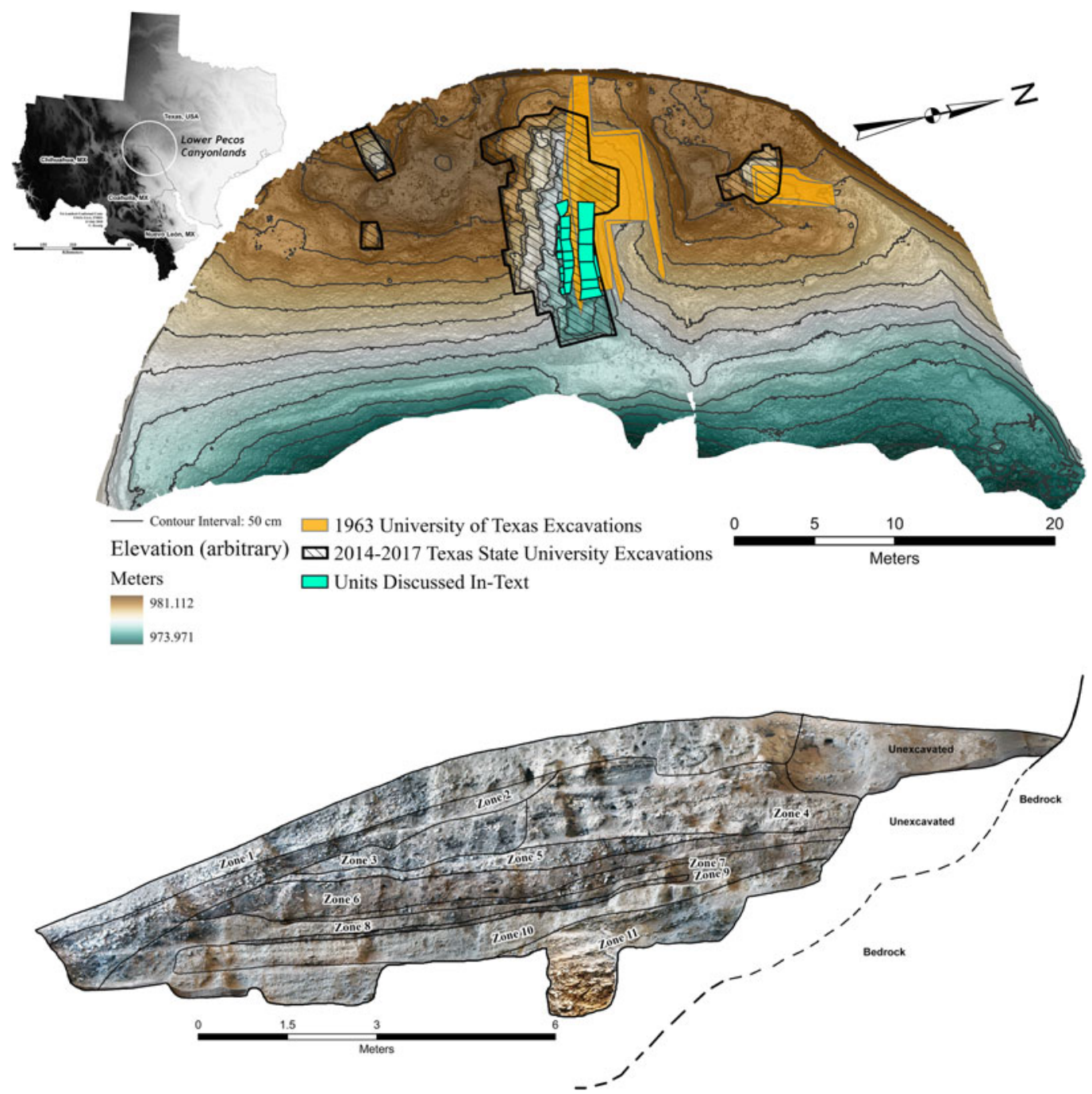

Figure 1. Top: Plan map of Eagle Cave showing the locations of the 1963 University of Texas and the 2014-2017 ASWT excavations and the location of the LPC (inset); the bold polygon in the center of the trench outlines the location of units discussed in the text. Bottom: Annotated Eagle Cave profile showing the stratigraphic positioning of the 10 major zones used in Bayesian modeling. (Color online)

Figure 4). Although excavators took one unit to bedrock, they did not screen, made few notes, and recovered no artifacts (Ross 1965:Figures 4 and 6). However, there were hints that Eagle Cave contained older cultural material. George C. Martin (Witte Museum) collected a possible Folsom point in 1939, but the whereabouts of this artifact are unknown. Ross (1965:62-63, Figure 13) recovered several lanceolate points but provided only basic descriptions and photographs, and Collins
(1991) speculated that Paleoindian deposits might lie toward the mouth of the cave. From 2014 to 2017, ASWT resumed work at Eagle Cave, investigating site formation processes, changes in Holocene subsistence patterns, earth oven intensification, and Paleoindian deposits. Because previous excavations were not backfilled, the slumped south wall of the Witte/UT trench provided an opportunity to conduct intensive stratigraphic excavations (Figure 1; Koenig et al. 2017). 


\section{Feature 14: A Younger Dryas Bison Butchery Component}

Feature 14 (F14) is a Paleoindian-age component containing faunal remains, lithic artifacts, and decomposed organics. In total, 22 excavation units across a $6 \times 3 \mathrm{~m}$ area sampled the F14 assemblage (Figure 2a). Intact F14 deposits were not encountered near the dripline or back wall of Eagle Cave, likely due to cultural and natural disturbances. Archaeological material recovered from F14 included fragmented faunal remains and lithic debitage with several subfeatures, including probable anvil stones (Feature 15), an in situ hearth (Feature 19), and a hearth cleanout (Feature 22; see Supplemental Text 1 for descriptions of Features 15 and 22).

\section{Stratigraphy and Chronology}

We subdivided the EC stratigraphy into 11 broad zones (Figure 1), with 41 AMS radiocarbon dates providing the chronological framework (Supplemental Table 1; Supplemental Figure 1). Within Zone 10-the Paleoindian-age deposits-we identified 16 strata made up primarily of frostshattered limestone spalls (eboulis sec) and endogenous sediments, with minor contributions of aeolian sediments (Figure 3; Supplemental Figure 2; Supplemental Table 2). The F14 component is primarily associated with strata S563 and S583, which are stratigraphically separated from the dense cultural deposit associated with Zone 9 (transitional Archaic; S594/UT Lens 14) and with S587, a bioturbated stratum older than 13,000 cal BP. Backplots of F14 artifacts indicate that the occupation is stratigraphically constrained and minimally displaced (Supplemental Figure 3). Bayesian modeling efforts focused on the basal portion of the EC sequence (Zones 10-8), with Zone 10 representing all Paleoindian-age deposits ( $>\sim 10,500$ cal BP), Zone 10/9 has two in situ hearths at the interface between Zones 10 and 9, and Zones 9 and 8 represent Late Paleoindian/transitional Archaic deposits (Figure 4; Supplemental Text 1). All dates were calibrated/modeled using the IntCal20 curve (Reimer et al. 2020) and OxCal 4.4 (Bronk Ramsey 2009a) and were assigned a 0.05 probability of being an outlier using the "General" outlier model within OxCal (Bronk
Ramsey 2009b). Modeled output is noted at a 95.4\% credible interval and rounded to five years. Bayesian modeling places the age of F14 at 12,660-12,480 cal BP during the Younger Dryas and contemporary with the Folsom period (Buchanan et al. 2021).

\section{Macrobotanical Analysis of the Feature 19 Hearth}

Feature $19(\mathrm{~F} 19)$ is a hearth measuring approximately $1 \times 1 \mathrm{~m}$ across. It consists of an ashy matrix (3-5 cm thick) containing charcoal and burned artifacts overlying a veneer of oxidized sediment $(3-7 \mathrm{~cm}$ thick; Supplemental Figure 4a). Several burned spalls were recovered from F19 (see Figure 2a), but F19 is a hearth, not an earth oven. Macrobotanical analysis focused on identifying fuelwood taxa and potential edible plants (Supplemental Text 1). The sample yielded 517 wood charcoal fragments larger than $2.0 \mathrm{~mm}$, of which 101 were identified to taxon (Table 1). Mesquite (Prosopis sp.) and juniper (Juniperus sp.) dominate the fuelwood assemblage; it also contains other less abundant taxa, including acacia (Acacia sp., sensu lato), possible joint fir (Ephedra sp.), oak (Quercus sp.), possible fourwing saltbush (Atriplex canescens), and wild grape (Vitis sp.). Except for grape, all identified F19 plant genera are present in roughly contemporaneous Chihuahuan Desert packrat middens (Van Devender 1990).

The most promising evidence for potential vegetal food is provided by several carbonized mesquite pericarp (pod) fragments, one of which was directly dated (D-AMS-24192; Supplemental Table 1). Although mesquite seeds are nutritionally rich (Earle and Jones 1962), human ingestion of the seeds is not as widespread as consumption of the pods, which are rich in sugars, carbohydrates, and protein (Choge et al. 2007). Mesquite is a seasonally dependable summer resource and an important food item across the US Southwest and northwest Mexico (e.g., Felger 1977). Although it is possible that mesquite pods were introduced into F19 as kindling, it is reasonable to infer that they were used as a summer food resource and that carbonization in F19 was caused by a toasting or parching accident. Regardless, the presence of mesquite pods suggests that the 


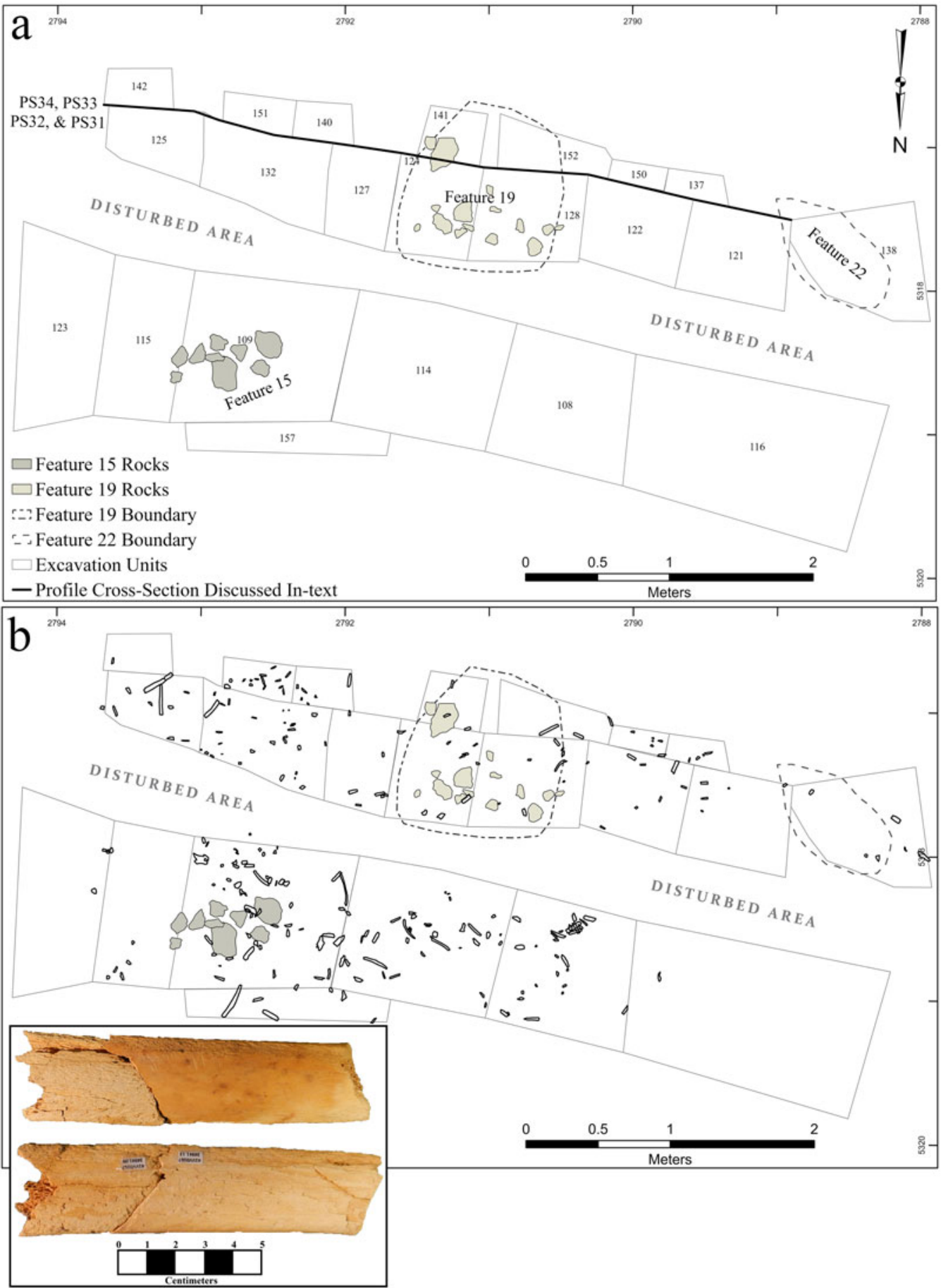

Figure 2. (a) Map of Feature 14 units and the locations of Feature 15 (probable anvil stones), Feature 19 (in situ hearth), and Feature 22 (hearth cleanout). Bold lines indicate horizontal locations of profiles discussed in the text. (b) Plan map of point-provenienced faunal remains with inset showing differential weathering between two refit bison bone fragments recovered approximately $50 \mathrm{~cm}$ apart. (Color online) 


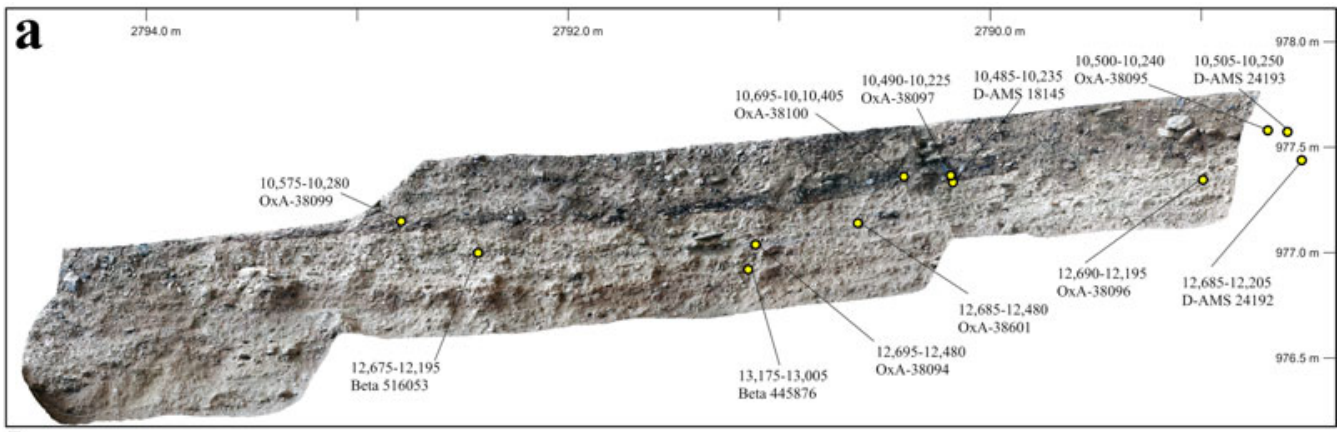

b
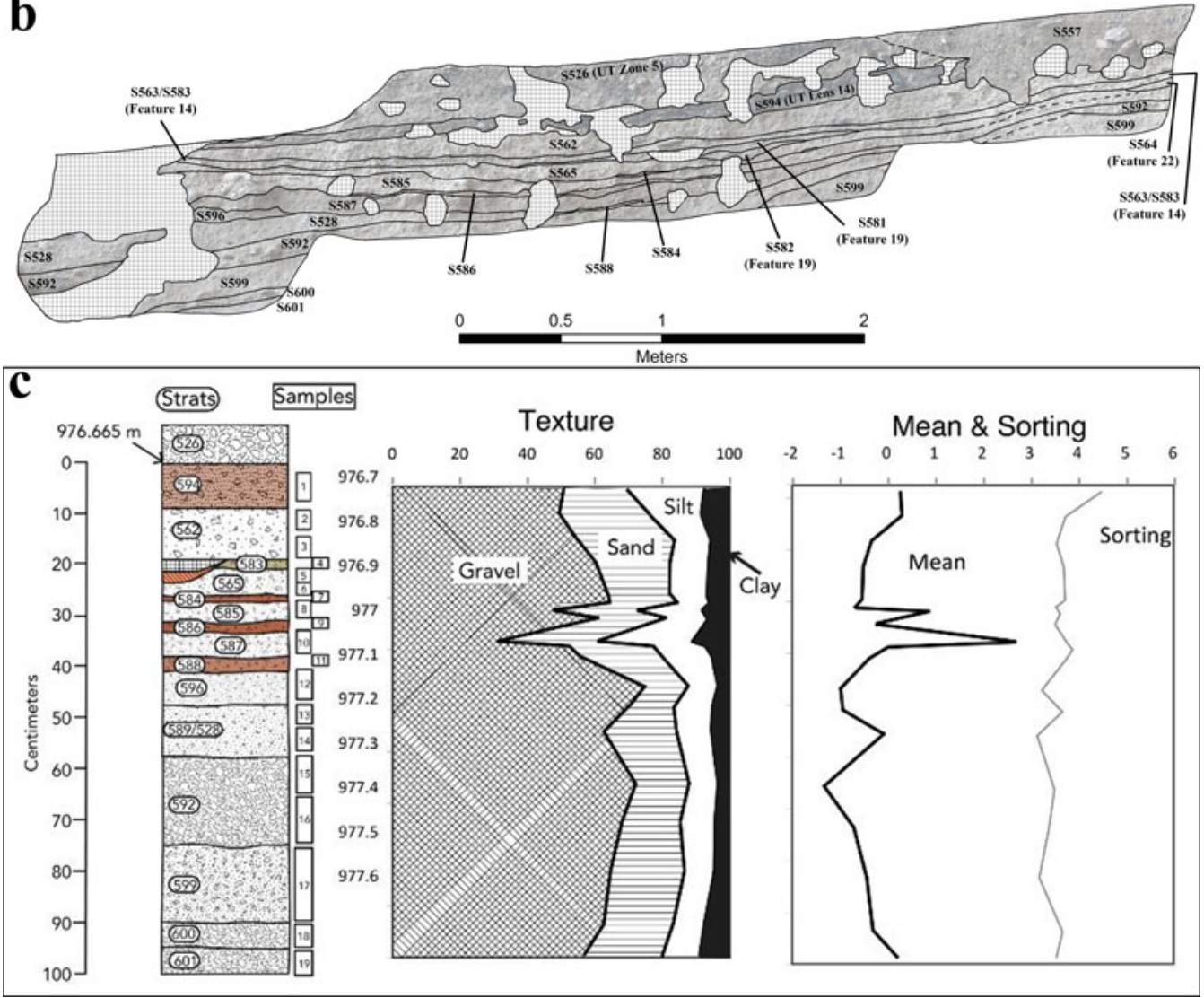

Figure 3. Orthographic image of late Pleistocene stratigraphy along profile sections (PS) 31, 32, 33, and 34 showing (a) terminal Pleistocene to early Holocene AMS dates; (b) annotated profile, and (c) geoarchaeological sediment analysis (color version online; see Supplemental Figure 2 for colorized annotation of PS31-34).

events associated with F14 occurred during the summer.

Although most of the F19 plant material is carbonized, macrobotanical analysis identified some uncarbonized material, including hackberry seeds (Celtis sp.) and juniper leaf scales (Table 1). It is conceivable that these uncarbonized items are intrusive from upper deposits, but the presence of uncarbonized plant material clearly associated with F19-including an uncarbonized fragment of mesquite wood (OxA-38601; Supplemental Table 1)—suggests that some uncarbonized flora are associated with F14. If they are related to human behavior, then hackberry fruits, prickly 


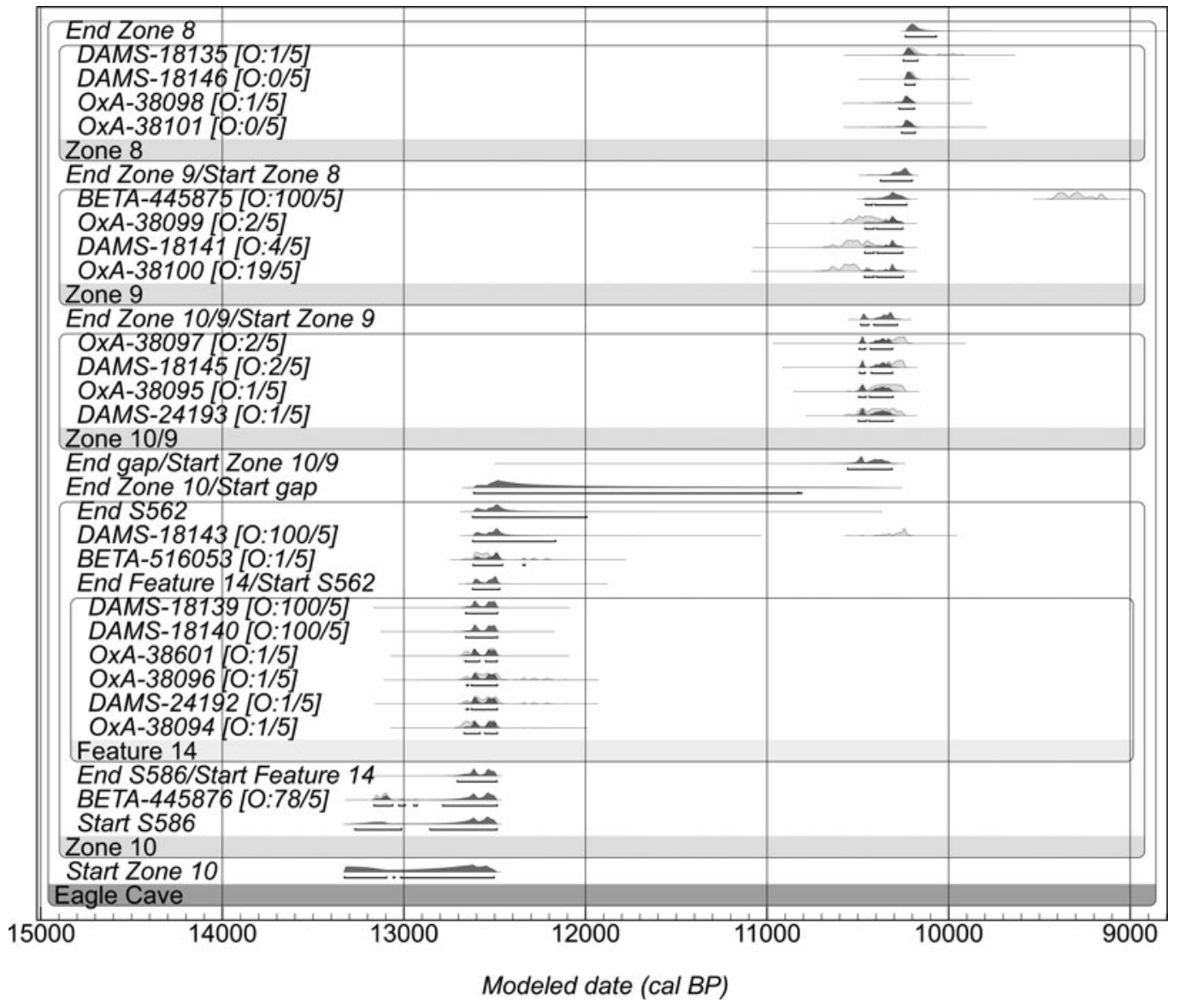

Figure 4. Bayesian age model of Eagle Cave, Zones 10-8. Outlier analysis output is noted as “O:posterior probability/ prior probability." Outliers are downweighted according to the posterior outlier probability. Oxcal code provided in Supplemental Text 1.

pear tunas, and bristlegrass grains may also have been on the menu.

\section{Feature 14 Faunal Assemblage}

A total of 225 point-provenienced, disarticulated (less than 10 refits) Bison antiquus bone fragments were recovered during excavation (Figure 2b; Supplemental Table 3). Based on mandibular tooth eruption $(n=2)$ and rib epiphyseal fusion $(n=56)$, the fragments were likely from a single Bison antiquus $(\mathrm{MNI}=1)$ between four and six years of age (Duffield 1973:Table 1). Additional point-provenienced faunal remains include a large bird, jackrabbit (Lepus californicus), deer (Odocoileus sp.), and mammoth (Mammuthus sp.), but a full faunal analysis-including examination of screened remains-has not been conducted. The mammoth bone $(n=2)$ is intrusive, originating from a stratum underlying F14, and is currently undergoing analysis.

Cultural modifications of bison bones include cutmarks, helical fractures, and blow marks consistent with marrow removal, roasting pattern burning, and informal tool manufacture. Ninety-eight of the 225 bones (44\%) had cutmarks, likely the result of filleting or defleshing consistent with secondary and tertiary butchering (Rixson 1988; Seetah 2006). The frequent occurrence of cutmarks within the F14 assemblage contrasts sharply with Younger Dryas bison kill sites on the southern Plains, further supporting the notion that portions of the bison were transported into Eagle Cave (Bement 2003; 
Table 1. Summary of Feature 19 Macrobotanical Results

\begin{tabular}{llccr}
\hline \multicolumn{1}{c}{ Fuelwood } & & \\
\hline \multicolumn{1}{c}{ Scientific Name } & Common Name & Count & $(\mathrm{g})$ & \% of Total $(n=101)$ \\
\hline Acacia spp., sensu lato & Acacia & 8 & 0.89 & 8 \\
cf. Atriplex canescens & Four-Wing Saltbrush & 1 & 0.07 & 1 \\
cf. Ephedra sp. & Joint Fir & 4 & 0.22 & 4 \\
Juniperus sp. & Juniper, Cedar & 23 & 1.32 & 23 \\
Prosopis sp. & Mesquite & 62 & 4.43 & 61 \\
Quercus sp. & Oak & 2 & 0.34 & 2 \\
Vitis sp. & Grape & 1 & 0.06 & 1 \\
\hline
\end{tabular}

Possible Plant Food Remains (Carbonized)

\begin{tabular}{lccl}
\hline \multicolumn{1}{c}{ Scientific Name } & Common Name & Count & \multicolumn{1}{c}{ Part } \\
\hline Prosopis sp. & Mesquite & 3 & Pericarp Fragment \\
Unidentifiable & & 1 & Seed Fragment \\
\hline
\end{tabular}

\begin{tabular}{lllll}
\hline & \multicolumn{2}{c}{ Uncarbonized Plant Remains* } & \\
\hline \multicolumn{1}{c}{ Scientific Name } & Common Name & Count & Part & Comments \\
\hline Celtis sp. & Hackberry & 2 & Seed & \\
Opuntia sp. & Prickly pear & 2 & Embryo & \\
Poaceae (cf. Setaria sp.) & Grass & 1 & Caryopsis & Plains bristlegrass \\
Unknown & & 1 & Fruit & Desiccated berry \\
Juniperus sp. & Juniper, Cedar & 26 & Leaf Scale & \\
Agavaceae/Liliaceae & Agave/sotol & 1 & Leaf Fiber & \\
\hline
\end{tabular}

*Possibly intrusive, may represent post-use natural deposition.

Bement and Carlson 2018). Only six bone fragments (ribs, lumbar vertebrae, or ischium) had evidence of primary processing and disarticulation. Sixteen bone fragments (ribs and long bones) had blow marks and helical fractures indicative of marrow or fat harvesting. Seven fragments show burning patterns consistent with roasting, suggesting minimal cooking or discard into F19.

Many of the bone fragments show taphonomic weathering, such as dry-state fractures and cracking (Stage 2 or Stage 3; Behrensmeyer 1978). Generally, it is expected that the downward side of bone fragments would be better preserved than the upward-facing side; however, some EC specimens were found with the wellpreserved side face up, indicating postdepositional disturbance. In at least one instance, two refitting fragments recovered approximately $50 \mathrm{~cm}$ apart demonstrate unequivocal postdepositional taphonomy (Figure $2 \mathrm{~b}$ inset). Given the lack of evidence of carnivore activity and the presence of bighorn sheep dung, we suggest that the F14 assemblage was trampled by bighorn sheep soon after the occupation (Mead et al. 2021; Supplemental Text 1).

\section{Feature 14 Lithic Assemblage}

The F14 lithic assemblage contains 1,040 artifacts: 7 biface fragments, 31 flake tools, and 1,002 pieces of debitage (Figure 5, Supplemental Figure $4 b)$. The bifaces are relatively small, fragmentary, and informal, representing a mix of tools and manufacturing rejects (Supplemental Text 1). One is a basal fragment of a narrow, tapering-stem, concave projectile point resembling the local Langtry variety (Turner et al. 2011:128; artifact 34485; see Figure 5 and Supplemental Figure 4b). However, we suspect for several reasons that this artifact was introduced from the UT/Witte trench: it was recovered from an area with the least vertical separation between F14 and the bottom of that trench, its base is inconsistent with known late Pleistocene types from the region, and it was recovered in relative isolation from other artifacts. 


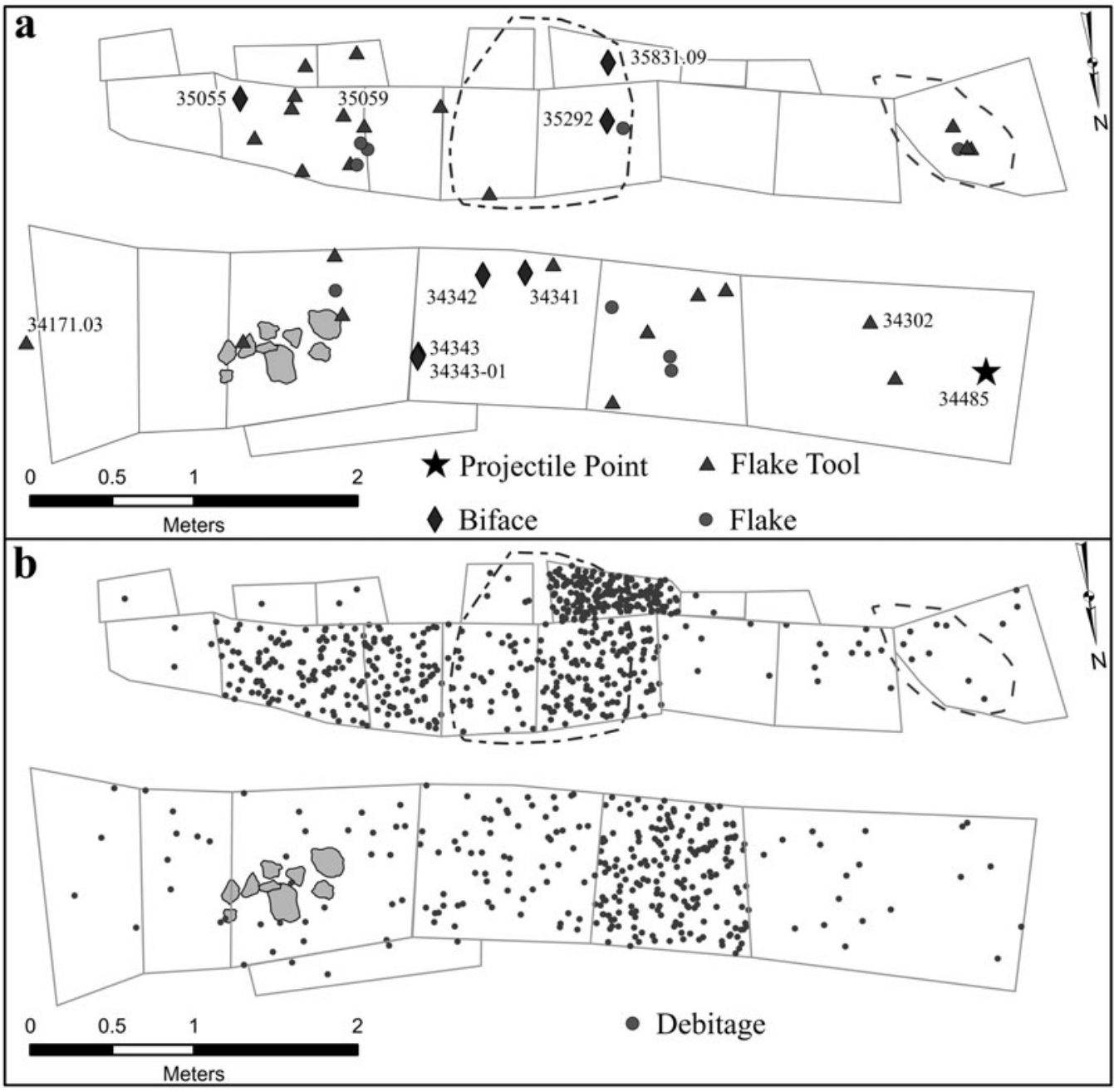

Figure 5. Plan maps of (a) point-plotted lithic tools and (b) randomized debitage by unit. Labeled lithics (a) correspond to formal tools in Supplemental Figure 4.

Debitage was distributed across F14 with concentrations surrounding F19 (Figure 5; Supplemental Table 4). It was examined $(n=$ $1,002)$ using minimum analytic nodule analysis (MANA; Larson and Kornfeld 1997) and technological flake classification (Root 2004) to address raw materials and tool maintenance and manufacture. In total, 18 analytic nodules were identified along with four indeterminate categories (Supplemental Table 5). Nodules 1 and 3 are likely Rio Grande gravels or Quaternary terrace deposits, and Nodule 2 appears to be heat-treated Edwards Plateau Chert. These three nodules comprised $53.3 \%$ of all debitage.
Though a limited sample size, F14 debitage provides a glimpse into raw materials, acquisition, tool manufacture, and maintenance activities. Raw materials appear to have been acquired from primary Edwards Plateau Chert sources, Rio Grande gravels, or Quaternary terrace deposits. Assuming that at least some of the Edwards material was curated as cores or blanks (Edwards material is locally available), the use of supplemental local materials is consistent with Folsom behavior (Boldurian 1990). The overall clarity of the MANA and the presence of tool refits $(n=3)$ indicate the site was occupied for a laborintensive short stay. Supporting this interpretation 
is the lack of ultrathin bifaces, knives, or heavy butchering tools. Debitage analysis indicates extensive bifacial reduction; however, the lack of channel flakes or broken preforms suggests that manufacture stopped short of finished points. In sum, the lithic tool and debitage analysis is consistent with F14 being a short stay during which people butchered and consumed a juvenile bison, maintained existing stone tools, and produced new ones through core reduction and biface manufacture on both transported and locally available raw materials.

\section{Summary and Conclusions}

Eagle Cave is a large rockshelter located in the Lower Pecos Canyonlands, and excavations by the Ancient Southwest Texas Project identified an extensive Younger Dryas component, Feature 14. The F14 assemblage consists of lithics, faunal remains, and one hearth with macrobotanical remains. The preliminary results reported here indicate that the artifact and faunal remains are associated with the post-transport processing of at least one juvenile Bison antiquus. Macrobotanical analysis of the hearth suggests the consumption of mesquite pods during a summer occupation. Even though no diagnostic artifacts were identified, Bayesian modeling indicates the occupation occurred between 12,660 and 12,480 cal BP, contemporaneous with Folsom (Buchanan et al. 2021). Although we lack sufficient chronometric data to demonstrate a behavioral link between F14 and Bone Bed 2 (BB2) at Bonfire Shelter, evaluating this possibility is an important avenue of future research. BB2 represents a summer kill and primary processing location with projectile points and articulated Bison antiquus remains (Bement 2007; Byerly et al. 2005; Kilby et al. 2021). The distinct differences in the faunal and lithic assemblages suggest that F14 could be a camp or activity area where portions of a bison were transported after a kill at Bonfire. However, the ages of BB2 $(12,000-11,500$ cal BP; Kilby et al. 2021:8) and F14 differ greatly, and additional dating and analysis are needed to evaluate their contemporaneity (Supplemental Text 1).

These results from Eagle Cave also emphasize the importance of conducting research on legacy collections and revisiting previously excavated sites. For instance, the F14 assemblage was not identified until a third round of excavations. Further, except for the diagnostic projectile points, perishable artifacts, and painted pebbles, the previous EC work remains underreported (Davenport 1938; Ross 1965)—an unfortunate reality for most LPC rockshelters (Black 2013). Additionally, if Early Paleoindian LPC rockshelter occupations are deeply buried beneath Archaic occupations and contain few diagnostic projectile points (as in EC), the excavation and sampling strategies during the 1930s to 1960s - which emphasized the recovery of formal tools - could have biased the archaeological recovery and recognition of late Pleistocene archaeology. The limited data, chronological and otherwise, from earlier excavated sites make it difficult to determine whether Paleoindian deposits exist unless diagnostic Paleoindian projectile points were recovered during excavations. Renewed work, beginning with analyzing existing collections and obtaining reliable radiocarbon dates, is necessary to expand our understanding of the Paleoindian period in the LPC. Work at EC suggests that new analyses of existing collections, focused study of previous excavations, and intensive radiocarbon dating may identify additional Early Paleoindian rockshelter assemblages in the LPC, as well as in other areas of North America.

Acknowledgments. The Skiles family and especially the late Jack Skiles have been unwavering supporters of archaeological work on their property; our ASWT work would not have been possible without them. Thank you to the 2014 2017 ASWT field crews and volunteers for making this study possible. Fieldwork was supported by the E. Thomas Miller Endowment at Texas State University, and Direct AMS dates were sponsored by Dating Eagle Cave crowdfunding donors. Special thanks to Thomas Higham and the staff of the Oxford Radiocarbon Accelerator Unit for supporting additional Eagle Cave dating efforts. Macrobotanical and geoarchaeological analysis was supported by a Frison Institute grant from the University of Wyoming. Phil Dering assisted the macrobotanical team, and Robert Kelly aided with editing. Diana Rolón graciously provided the Spanish translation of the abstract. Comments from Bryan Hockett and two anonymous reviewers greatly improved the final manuscript.

Data Availability Statement. All ASWT Eagle Cave artifacts and data are housed at Texas State University and the Center for Archaeological Studies. 
Supplemental Material. For supplemental material accompanying this report, visit https://doi.org/10.1017/aaq.2021. 126.

Supplemental Text 1. Explanations of LPC late Pleistocene sites, excavation methodology, features, radiocarbon dating, macrobotanical, dung, lithic analyses, and the connection between Feature 14 and Bone Bed 2 at Bonfire Shelter.

Supplemental Figure 1. Eagle Cave profile showing locations of all 41 AMS dates.

Supplemental Figure 2. Colorized stratigraphic annotation of combined profile sections 31, 32, 33, and 34 .

Supplemental Figure 3. (a) Backplots onto profile sections (PS) 31-34 of all faunal remains; (b) point-provenienced lithic tools; and (c) randomized debitage by unit associated with the Feature 14 assemblage.

Supplemental Figure 4. Cross section of Feature 19: (a) the ash and charcoal-rich layer of the hearth overlaying the oxidized/rubified rockshelter sediments; (b) sample of lithic tools recovered during excavation of Feature 14: Langtry projectile point (34485), flake tools (35059 and 34302), and bifaces $(34171.03, \quad 34341, \quad 34342, \quad 35292,35831.09,34343$, $34343-01$, and 35055). Artifact numbers correspond to locations in Figure 5.

Supplemental Table 1. Eagle Cave AMS Radiocarbon Samples Collected by the ASWT Project.

Supplemental Table 2. Descriptions of Stratigraphic Layers.

Supplemental Table 3. Summary of Point-Provenienced Bison antiquus Remains Recovered from Feature 14 and Cultural Modification.

Supplemental Table 4. Debitage Counts by Unit and Analytical Nodule.

Supplemental Table 5. Description of Analytical Nodules Identified during Debitage Analysis.

\section{References Cited}

Behrensmeyer, Anna K.

1978 Taphonomic and Ecologic Information from Bone Weathering. Paleobiology 4:150-162.

Bement, Leland C.

1986 Excavation of the Late Pleistocene Deposits of Bonfire Shelter, 41VV218, Val Verde County, Texas 1983-1984. Archeology Series 1. Texas Archeological Survey, University of Texas, Austin.

2003 Constructing the Cooper Model of Folsom Bison Kills on the Southern Plains. Great Plains Research 13:27-41.

2007 Bonfire Shelter: A Jumping-Off Point for Comments for Byerly et al. American Antiquity 72:366-372.

Bement, Leland C., and Kristen Carlson

2018 On the Significance of Cutmark Distributions at the Badger Hole Folsom Bison Arroyo Trap, Southern Plains, USA. PaleoAmerica 4:31-42.

Black, Stephen L.

2013 The Archaeologists. In Painters in Prehistory: Archaeology and Art of the Lower Pecos Canyonlands, edited by Harry J. Shafer, pp. 139-152. Trinity University Press, San Antonio.

Boldurian, Anthony

1990 Lithic Technology at the Mitchell Locality of Blackwater Draw: A Stratified Folsom Site in Eastern New
Mexico. Plains Anthropologist Vol. 35, No. 130. Memoir No. 24. Plains Anthropological Society, Lincoln, Nebraska.

Bousman, C. Britt, Barry W. Baker, and Anne C. Kerr

2004 Paleoindian Archeology in Texas. In The Prehistory of Texas, edited by Timothy K. Perttula, pp. 15-97. Texas A\&M University Press, College Station.

Boyd, Carolyn E.

2016 The White Shaman Mural: An Enduring Creation Narrative in the Rock Art of the Lower Pecos. University of Texas Press, Austin.

Bronk Ramsey, C.

2009a Bayesian Analysis of Radiocarbon Dates. Radiocarbon 51:337-360.

2009b Dealing with Outliers and Offsets in Radiocarbon Dating. Radiocarbon 51:1023-1045.

Buchanan, Briggs, J. David Kilby, Marcus J. Hamilton, Jason M. LaBelle, Kelton A. Meyer, Jacob Holland-Lulewicz, Brian Andrews, et al.

2021 Bayesian Revision of the Folsom Age Range Using IntCal20. PaleoAmerica 7:133-144. DOI:10.1080/ 20555563.2021.1890401.

Byerly, Ryan M., Judith R. Cooper, David J. Meltzer, Matthew E. Hill, and Jason M. LaBelle

2005 On Bonfire Shelter (Texas) as a Paleoindian Bison Jump: An Assessment Using GIS and Zooarchaeology. American Antiquity 70:595-629.

Choge, S. K., N. M Pasiecznik, M. Harvey, J. Wright, S. Z Awan, and P. J. C. Harris

2007 Prosopis Pods as Human Food, with Special Reference to Kenya. Water SA 33:419-424.

Collins, Michael B.

1991 Rockshelters and the Early Archaeological Record in the Americas. In The First Americans: Search and Research, edited by Tom D. Dillehay and David J. Meltzer, pp. 157-182. CRC Press, Boca Raton, Florida Davenport, J. Walker

1938 Archaeological Exploration of Eagle Cave, Langtry, Texas. Big Bend Basket Maker Papers No. 4. Witte Memorial Museum, San Antonio, Texas.

Dibble, David S., and Dessamae Lorrain

1968 Bonfire Shelter: A Stratified Bison Kill Site, Val Verde County, Texas. Miscellaneous Papers 1. Texas Memorial Museum Publications, University of Texas, Austin.

Duffield, Lathel F.

1973 Aging and Sexing the Post-Cranial Skeleton of Bison. Plains Anthropologist 18:132-139.

Earle, Fontaine R., and Quintin Jones

1962 Analysis of Seed Samples from 113 Plant Families. Economic Botany 16:221-250.

Felger, Richard S.

1977 Mesquite in Indian Cultures of Southwestern North America. In Mesquite: Its Biology in Two Desert Ecosystems, edited by B. B. Simpson, pp. 150-175. Dowden, Hutchinson, and Ross, Stroudsberg, Pennsylvania.

Holliday, Vance T.

1997 Paleoindian Geoarchaeology of the Southern High Plains. University of Texas Press, Austin.

Jurgens, Christopher J.

2005 Zooarcheology and Bone Technology from Arenosa Shelter (41VV99), Lower Pecos Region, Texas. PhD dissertation, Anthropology Department, University of Texas. Austin.

Kilby, J. David, Sean P. Farrell, and Marcus J. Hamilton 2021 New Investigations at Bonfire Shelter, Texas 
Examine Controversial Bison Jumps and Bone Beds. Plains Anthropologist 66:34-57.

Koenig, Charles W., Mark D. Willis, and Stephen L. Black 2017 Beyond the Square Hole: Application of Structure from Motion Photogrammetry to Archaeological Excavation. Advances in Archaeological Practice 5:54-70.

Larson, Mary Lou, and Marcel Kornfeld

1997 Chipped Stone Nodules: Theory, Method, and Examples. Lithic Tecnology 22:4-18.

Lundelius, Ernest.

1984 A Late Pleistocene Mammalian Fauna from Cueva Quebrada, Val Verde County, Texas. In Contributions in Quaternary Vertebrate Paleontology: A Volume in Memorial to John E. Guilday, edited by Hugh H. Genoways and Mary R. Dawson, pp. 456-481. Special Publication 8. Carnegie Museum of Natural History, Pittsburgh, Pennsylvania.

Mead, Jim I., Charles W. Koenig, Stephen L. Black, and Christopher J. Jurgens

2021 Late Pleistocene Bighorn Sheep Dung from Eagle Cave, Lower Pecos River, Texas. Southwestern Naturalist 65:152-160.

Norris, James E., Alyssa Perrone, G. Logan Miller, Briggs Buchanan, Robert J. Patten, Michelle R. Bebber, and Metin I. Eren

2019 Description, Morphometrics, and Microwear of Two Clovis Points from Pandale, Val Verde County, Texas. Bulletin of the Texas Archeological Society 90:151-158.

Reimer, Paula J., William E. N. Austin, Edouard Bard, Alex Bayliss, Paul G. Blackwell, Christopher Bronk Ramsey, Martin Butzin, et al.

2020 The IntCal20 Northern Hemisphere Radiocarbon Age Calibration Curve (0-55 cal kBP). Radiocarbon 62:725-757.

Rixson, Derrick

1988 Butchery Evidence on Animal Bones. Circaea 6:49-62.

Root, Mathew J.

2004 Technological Analysis of Flake Debris and the
Limitations of Size-Grade Technique. In Aggregate Analysis in Chipped Stone, edited by Christopher T. Hall and Mary Lou Larson, pp. 65-94. University of Utah Press, Salt Lake City

Ross, Richard E.

1965 The Archaeology of Eagle Cave. Papers of the Texas Archeological Salvage Project No. 7. University of Texas, Austin.

Sayles, E. B.

1935 An Archaeological Survey of Texas. Gila Pueblo, Globe, Arizona.

Seetah, Krish

2006 The Importance of Cut Placement and Implement Signatures to Butchery Interpretation. Essay Prize Submission, 10th Conference of the International Council for Archaeozoology, Mexico City.

Shafer, Harry J.

2013 Painters in Prehistory: Archaeology and Art of the Lower Pecos Canyonlands. Trinity University Press, San Antonio.

Turner, Ellen Sue, Thomas R. Hester, and Richard L McReynolds

2011 Stone Artifacts of Texas. 3rd ed. Taylor Trade Publishing, Lanham, Maryland.

Turpin, Solveig A., and Herbert H. Eling Jr.

2017 An Expanded Inventory of Radiocarbon Dates from the Lower Pecos River Region of Texas and the Northern Mexican States of Coahuila and Nuevo León. Bulletin of the Texas Archeological Society 88:105-131.

Van Devender, Thomas R.

1990 Late Quaternary Vegetation and Climate of the Chihuahuan Desert, United States and Mexico. In Packrat Middens: The Last 40,000 years of Biotic Change, edited by Julio L. Batencourt, Thomas R. Van Devender, and Paul S. Martin, pp. 104-133. University of Arizona Press, Tucson.

Submitted April 12, 2021; Revised July 9, 2021; Accepted September 20, 2021 